\title{
Predictors of frailty in older people users of Primary Health Care
}

\author{
Preditores da fragilidade no idoso usuário da Atenção Primária à Saúde \\ Predictores de fragilidad en usuarios mayores de Atención Primaria de Salud
}

João Paulo de Almeida Tavares' ORCID: 0000-0003-3027-7978

Pedro Miguel Ferreira de Sá-Couto" ORCID:0000-0002-5673-8683

Larissa Chaves Pedreira"II ORCID:0000-0001-8939-324X

'Universidade de Aveiro, Escola Superior de Saúde. Aveiro, Portugal.

"Universidade de Aveiro, Departamento de Matemática. Aveiro, Portugal.

I' Universidade Federal da Bahia. Salvador, Bahia, Brazil.

How to cite this article: Tavares JPA, Sá-Couto PMF, Pedreira LC. Predictors of frailty in older people users of Primary Health Care. Rev Bras Enferm. 2022;75(Suppl 4):e20201292. https://doi. org/10.1590/0034-7167-2020-1292

\section{Corresponding author:} João Tavares

E-mail: joaoptavares@ua.pt

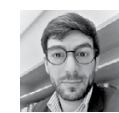

EDITOR IN CHIEF: Dulce Barbosa ASSOCIATE EDITOR: Priscilla Broca

Submission: $12-21-2020$

Approval: 09-19-202

\begin{abstract}
Objective: to identify the prevalence and predictors of frailty in older people in Primary Health Care. Method: this is a descriptive and correlational study, carried out in a convenience sample of 136 older people in the community. Data were collected through a sociodemographic and clinical questionnaire and frailty phenotype. Student's t test or U-Mann-Whitney test, chi-square and binary logistic regression were used for data analysis. Results: the prevalence of frailty was $26.5 \%(n=36)$. Frail individuals had older age $(p=0.011)$, worse self-rated health $(p=0.001)$ and lower physical capacity $(p<0.001)$. In the multivariable regression, it was observed that frail individuals had older age (Odds Ratio $=1.111 ; 95 \%$ confidence interval $=1.026-1.203$ ) and worse physical capacity (Odds Ratio $=0.673 ; 95 \%$ confidence interval $=0.508-0.893$ ). Conclusions: the prevalence of frailty in older people in Primary Health Care was considerable. Advanced age and worse physical capacity were the most relevant predictors of frailty in the elderly.
\end{abstract}

Descriptors: Elderly; Health of the Elderly; Frailty; Prevalence; Primary Health Care.

\section{RESUMO}

Objetivo: identificar a prevalência e preditores da fragilidade de idosos na Atenção Primária à Saúde. Método: estudo descritivo e correlacional, realizado em amostra de conveniência com 136 idosos na comunidade. Os dados foram coletados através de um questionário sociodemográfico, clínico e pelo fenótipo de fragilidade. Utilizaram-se o teste $t$ de Student ou U-Mann-Whitney, o Qui-Quadrado e a regressão logística binária na análise dos dados. Resultados: a prevalência da fragilidade foi de $26,5 \%(n=36)$. Os idosos frágeis apresentaram idade mais avançada $(p=0,011)$, pior autoavaliação de saúde $(p=0,001)$ e menor capacidade física $(p<0,001)$. Na regressão multivariável, observou-se que os idosos frágeis apresentavam idade mais avançada (Odds Ratio $=1,111$; Intervalo de Confiança $95 \%=1,026-1,203$ ) e pior capacidade física (Odds Ratio $=0,673$; Intervalo de Confiança $95 \%=0,508-0,893$ ). Conclusões: a prevalência da fragilidade nos idosos na Atenção Primária à Saúde foi considerável. A idade avançada e a pior capacidade física foram os preditores mais relevantes da fragilidade nos idosos. Descritores: Idoso; Saúde do Idoso; Fragilidade; Prevalência; Atenção Primária à Saúde.

\section{RESUMEN}

Objetivo: identificar la prevalencia y predictores de fragilidad en ancianos en Atención Primaria de Salud. Método: estudio descriptivo y correlacional, realizado en una muestra de conveniencia con 136 ancianos de la comunidad. Los datos fueron recolectados a través de un cuestionario sociodemográfico, clínico y de fenotipo de fragilidad. Para el análisis de los datos se utilizaron la prueba t de Student o la prueba U-Mann-Whitney, chi-cuadrado y regresión logística binaria. Resultados: la prevalencia de fragilidad fue del $26,5 \%(n=36)$. Los ancianos frágiles eran mayores $(p=0,011)$, peor autoevaluación de la salud $(p=0,001)$ y menos capaces físicamente $(\mathrm{p}<0,001)$. En la regresión multivariante, se observó que los ancianos frágiles eran mayores (Odds Ratio $=1,111$; Intervalo de confianza del $95 \%=1,026$ 1,203 ) y peor capacidad física (Odds Ratio $=0,673$; Intervalo de confianza del $95 \%=0,508$ 0,893 ). Conclusiones: la prevalencia de fragilidad en ancianos en Atención Primaria de Salud fue considerable. La edad avanzada y la peor capacidad física fueron los predictores más relevantes de fragilidad en el anciano

Descriptores: Anciano; Salud del Anciano; Fragilidad; Prevalencia; Atención Primaria de Salud. 


\section{INTRODUCTION}

With the aging of the population, the frailty syndrome (FS) emerges as an emerging phenomenon with implications for public health and clinical practice ${ }^{(1)}$. In the search for an explanation for this syndrome, the investigation of the last three decades has given rise to three models: phenotypic or biological(2), accumulated deficit ${ }^{(3)}$ and comprehensive ${ }^{(4)}$. Although there is no unanimous definition related to FS, in 2013 a consensus reported it as a medical syndrome with multiple causes and contributing factors, characterized by decreased strength, endurance and physiological functions, which increase an individual's vulnerability to develop functional dependence and/or die ${ }^{(5)}$.

The clinical picture presented in the FS situation increases the vulnerability of individuals when exposed to a stress factor, to negative outcomes, such as organic instability, functional disability/dependence, institutionalization, falls, acute illnesses, hospitalization, increased demand for health care, poor recovery, high risk of iatrogenesis and death ${ }^{(6)}$.

A review work ( $n=43$ studies) reported an estimated prevalence of FH in the community, assessed through the frailty phenotype (FP), of $12 \%$, with a prevalence rate between 10 and $14 \%{ }^{(7)}$. More than $50 \%$ of people in the community aged 50 and over were considered pre-frail or frail in another study, predominantly women ${ }^{(8)}$. However, it is estimated that a quarter to half of people aged 85 years and over have FS, and the prevalence of frailty increases with age $\mathrm{e}^{(9)}$. However, despite this information, FS is not synonymous with advanced age, multimorbidity or disability ${ }^{(2)}$. Additionally, a systematic review of population studies ( $\mathrm{n}=11$ studies) showed that $\mathrm{FS}$ is prevalent and is associated with a decrease in the survival of older people ${ }^{(10)}$. In Portugal, data on the prevalence of FS in the community, in different studies, ranged between $34.5 \%$ and $36.5 \%{ }^{(11-13)}$.

FS appears related to different risk factors, and its wide variability of aspects and conditions is consensual, including sociodemographic, clinical, lifestyle and biological domains ${ }^{(1)}$. Additionally, the vulnerability inherent to this syndrome emerges not only from the number of risk factors, but from their interaction - a concentric interactive model. Significant sociodemographic and clinical predictors, reported in systematic review studies, were old age, female, ethnicity, access to health care, low education, low socioeconomic status/social vulnerability, isolation and/or loneliness, obesity, malnutrition, depression, cognitive deficit, multimorbidity, smoking, excessive alcohol consumption and physical inactivity ${ }^{(9,14)}$.

Currently Portugal is the fourth oldest country in the world, which is reflected in the demand for health care, especially in Primary Health Care (PHC). The influence of geographic, cultural and sociodemographic differences on frailty underlines the importance of studying this syndrome in specific contexts. In Portugal, studies on predictors of frailty are scarce, especially in PHC. Thus, knowing these predictors by health professionals, especially nurses, can promote the recognition of frailty and implement interventions for potentially modifiable predictors.

\section{OBJECTIVE}

To identify the prevalence and predictors of FS of older people in $\mathrm{PHC}$.

\section{METHODS}

\section{Ethical aspects}

The study was approved by the Regional Health Administration Ethics Committee. Participation was anonymous and voluntary and all participants signed the Informed Consent Form.

\section{Study design, place and period}

This is a quantitative, descriptive and correlational study, carried out in a Family Health Unit (FHU) belonging to the city of Vila Nova de Gaia, Northern Regional Health Administration (RHA), in Portugal. The collection took place between April and July 2017. For the preparation of the manuscript, the Strengthening the Reporting of Observational Studies in Epidemiology (STROBE) recommendations were followed.

\section{Sample, and inclusion and exclusion criteria}

The sampling was non-random for convenience. Inclusion criteria were being 65 years of age or older and going to a routine medical or nursing consultation at the FHU. People with gait and visual impairments, who prevented the performance of physical performance tests (inability to stand and walk independently), inability to communicate orally, elderly residents of long-term care facilities and with a history of neurocognitive disturbance (confirmed by clinical and/or family history) were excluded. Considering a range of $95 \%$ confidence intervals not exceeding $10 \%$, with an estimated proportion of FS in the community of $12 \%$ (assessed by the FP scale) $^{(7)}$, the estimated value for the sample size was 163 subjects. However, due to logistical issues regarding the place of collection, only a convenience sample of 136 older people in the community was obtained.

\section{Study protocol}

Data collection took place between April and June 2017, in which the investigator spent three times a week, two between 2 p.m. and 5 p.m. and one between 11 a.m. and 3 p.m., in a private room provided by the unit. Assessment of older people took place in a single consultation during this period. When older people arrived at the health unit, they were approached by the unit's professionals about their availability and agreement to participate in the study. Persons who agreed were referred to the researcher responsible for data collection (IM). Data collection took place through a structured interview with multiple filling out of the questionnaire, followed by performance tests. The questionnaire consists of sociodemographic, family and clinical characterization, and FP. The characterization included sex, age, marital status, education level, cohabitation (with whom they live and how many people live in the same house), clinical history, reason for going to the FHU, self-rated health (1 to 5), weight, height and self-rated physical capacity (0 to 10 ).

$\mathrm{FP}$ is one of the most robust assessment methods for clinical use $^{(15)}$ and was developed by Fried and colleagues ${ }^{(2)}$ who identified a cluster of five physical components that arise in vulnerable older people (syndromic approach) (Chart 1). This phenotype 
has been validated and replicated in different population-based studies. Participants who had three or more components were considered frail, while those with less than three components were considered non-frail (less than three components). It should be emphasized that the pre-frail stage (one or two components) was not considered, as reported in other studies ${ }^{(16)}$.

A systematic review study identified 264 studies with versions of the FP published in recent years; however, only 24 studies ensured the original version assumptions ${ }^{(17)}$. In Portugal, Duarte ${ }^{(18)}$ proposes an adapted version of the FP in the community, which ensured the criteria proposed by Fried and colleagues (Chart 1$)^{(2)}$ and confirmed the predictive validity of the adapted FP with adverse outcomes and concurrent validity with the Groningen Frailty Indicator ${ }^{(18)}$.

Hand grip strength was measured with a Support/GRIP-D dynamometer. This reads strength in $\mathrm{kg}$ and has a reliability between moderate and excellent. Although there is no consensus on the assessment protocol ${ }^{(19)}$, in this study, the strength in the dominant upper limb was evaluated twice and the highest value of the two measurements was used in the statistical analysis. In addition to cut-offs $A^{(20)}$, other cut-off values were considered: $16 \mathrm{~kg}$ for women and $27 \mathrm{~kg}$ for men (cut-offs B) ${ }^{(21)}$ and $16 \mathrm{~kg}$ for women and $26 \mathrm{~kg}$ for men (cut-offs $C$ ) ${ }^{(22)}$. In this study, although cut-offs $A$ were used as a reference, these different cut-offs were analyzed in determining the frailty of older people in the community.

Chart 1 - Adapted version of the frailty phenotype, Porto, Portugal, 2015

\begin{tabular}{|c|c|}
\hline Frailty phenotype & Adjusted Model \\
\hline $\begin{array}{l}\text { Weight loss - } \\
\text { Unintentional weight loss } \\
\text { in the last year, less than } \\
5 \% \text { of body weight }\end{array}$ & $\begin{array}{l}\text { Nutritional disorders - Have you lost or } \\
\text { gained weight for no apparent reason in } \\
\text { the past } 6 \text { months? Have you been eating } \\
\text { worse from lack of appetite? } \\
\text { Phenotype quotation: } \mathrm{No}=0 / \text { Yes }=1\end{array}$ \\
\hline $\begin{array}{l}\text { Resistance/exhaustion - } \\
\text { Depression Scale (CES-D) } \\
\text { a) I felt that all I did was } \\
\text { an effort and b) I couldn't } \\
\text { keep going }\end{array}$ & $\begin{array}{l}\text { Geriatric Depression Scale (GDS) - Do you } \\
\text { feel full of energy? } \\
\text { Phenotype quotation: } \mathrm{No}=0 / \text { Yes }=1\end{array}$ \\
\hline $\begin{array}{l}\text { Physical activity/energy } \\
\text { expenditure - Minnesota } \\
\text { Activity and Leisure Quiz }\end{array}$ & $\begin{array}{l}\text { Time Occupancy Scale - Do you usually } \\
\text { practice sports activities (swimming, } \\
\text { cycling, walking, gymnastics, fitness)? } \\
\text { Phenotype quotation: } \mathrm{No}=1 / \text { Yes }=0\end{array}$ \\
\hline $\begin{array}{l}\text { Slowness/walking } \\
\text { time - walking time, } 15 \\
\text { steps, sex and height } \\
\text { stratification }\end{array}$ & $\begin{array}{l}\text { Timed Up and Go (TUG) test - } \\
<10 \text { seconds=independent } \\
\geq 10 \text { seconds=some dependency } \\
\text { Phenotype quotation: } \text { No=0/Yes }=1\end{array}$ \\
\hline $\begin{array}{l}\text { Weakness/hand strength } \\
\text { - Handgrip strength } \\
\text { stratified by sex and body } \\
\text { mass index (BMI) quartiles }\end{array}$ & $\begin{array}{l}\text { Handgrip Strength - Stratified by Sex } \\
\text { (Men } \geq 31 \text { Women } \geq 18 \text { Kilogram }(\mathrm{kg}),- \\
\text { cut-offs A) } \\
\text { Phenotype quotation: } \mathrm{No}=0 / \text { Yes }=1\end{array}$ \\
\hline
\end{tabular}

\section{Analysis of results, and statistics}

Methods of comparison of two groups of independent samples were used to detect significant differences between the groups of frail and non-frail older people (based on the classification obtained by FP). The parametric Student's t test of independent samples was used when the assumption of normality was verified (through the visualization of the QQ plot). Otherwise, the nonparametric Mann-Whitney $U$ test was used ${ }^{(23)}$. We also used the chi-square test for contingency tables to identify associations between qualitative variables and the classification of older people as frail and non-frail(23). Statistical predictive models for FS (binary logistic regression models) were constructed using the instruments used and sociodemographic, family and clinical variables as independent variables. The approach consisted of identification of significant variables in the univariate model (1 dependent variable and one independent variable) and construction of the multivariate model ( 1 dependent variable and several significant independent variables) only with the significant variables obtained in the univariate model ${ }^{(24)}$. Values were presented in an Odds Ratio (OR) format and the respective $95 \%$ confidence intervals $(95 \% \mathrm{Cl})$. The Cox-Snell and Nagelkerke R2 pseudo-R2 values were calculated and the Hosmer and Lemeshow fit test was applied. The IBM Statistical Package for Social Sciences (SPSS) - version 25 was used as statistical support, considered a $p$ value $<0.05$ as statistically significant.

\section{RESULTS}

\section{Sample characterization}

Seventy participants (51.5\%) were women, with a mean ( \pm standard deviation) age of $74 \pm 6.2$ years. Most were married $(n=104 ; 76.5 \%)$ and had attended primary $(n=71 ; 52.2 \%)$ or elementary school $(n=24 ; 17.6 \%)$. More than half live with a spouse $(n=78,57.4 \%)$ or with a spouse and family $(n=27,19.9 \%)$. Seventy older people self-rated their health as good (51.5\%), 47 as acceptable (34.6\%), 11 as very good (8.1\%) and eight as poor or very poor $(5.9 \%)$. The routine consultation was the main reason for going to the FHU $(n=107 ; 78.7 \%)$, followed by specific medical consultations $(n=9,6.6)$, examinations $(n=6,4.4 \%)$ and nursing consultations $(n=5,3.7 \%)$. Regarding the clinical history, hypertension ( $n=98,72.1 \%)$, hypercholesterolemia $(n=93,68.4 \%)$ and diabetes $(n=44,32.4 \%)$ stood out. The mean weight was $71.6 \pm 12.9 \mathrm{~kg}$ and the mean height was $1.63 \pm 0.09$ meters $(\mathrm{m})$. The mean body mass index (BMI) was $27.1 \pm 4.5\left(\mathrm{~kg} / \mathrm{m}^{2}\right)$, and it was found that $11.0 \%$ of respondents had low weight $(\mathrm{BMl}<22$ $\mathrm{kg} / \mathrm{m}^{2}$ ), 40.4\% were eutrophic (BMI between 22 to $27 \mathrm{~kg} / \mathrm{m}^{2}$ ) and $48.5 \%$ were overweight $\left(\mathrm{BMl}>27 \mathrm{~kg} / \mathrm{m}^{2}\right)$.

\section{Frailty characterization}

The prevalence of frail older people (three or more criteria in the FP) was $36(26.5 \%)$. Of the phenotype domains, low activity level $(n=76 ; 55.9 \%)$, slowness $(n=88 ; 64.7 \%$ of respondents exceeds the time limit $\geq 10$ seconds) and weakness/decrease in hand grip strength ( $n=51 ; 37.8 \%$ ) stand out (Table 1$)$. In the distribution of scores obtained by the FP instrument, it was found that 25 (18.4\%), 37 (27.2\%), 38 (27.9\%), 29 (21.3\%) and 7 (5.1\%) had 0, 1, 2, 3 and 4 scores, respectively.

In the weakness dimension (hand grip strength), in absolute terms, males presented a higher mean $(33.7 \pm 7.8 \mathrm{~kg})$ than females $(19.7 \pm 7.2 \mathrm{~kg})$. Considering the left dominant hand $(n=3)$, males had a higher mean $(n=1,24.5 \mathrm{~kg})$ than females $(n=2,20.1 \pm 0.4 \mathrm{~kg})$. In the right dominant hand $(\mathrm{n}=132)$, males presented a higher mean $(n=65,33.9 \pm 7.8 \mathrm{~kg})$ than females $(n=67,20.1 \pm 0.4)$. 
Table 1 - Frailty phenotype characterization according to the five domains ( $N=136)$, Porto metropolitan area, Vila Nova de Gaia, Portugal, 2017

\begin{tabular}{|c|c|c|}
\hline \multirow{2}{*}{$\begin{array}{l}\text { Dimensions } \\
\begin{array}{l}\text { Weight loss } \\
\text { D1 }\end{array}\end{array}$} & \multicolumn{2}{|c|}{ Phenotype n (\%) } \\
\hline & $\begin{array}{c}\text { No } \\
136(100)\end{array}$ & $\begin{array}{l}\text { Yes } \\
0(0)\end{array}$ \\
\hline $\begin{array}{l}\text { Resistance } \\
\text { D2 }\end{array}$ & $\begin{array}{c}\text { Yes } \\
123(90.4)\end{array}$ & $\begin{array}{c}\text { No } \\
13(9.6)\end{array}$ \\
\hline $\begin{array}{l}\text { Physical activity } \\
\text { D3 }\end{array}$ & $\begin{array}{c}\text { Yes } \\
60(44.1)\end{array}$ & $\begin{array}{c}\text { No } \\
76(55.9)\end{array}$ \\
\hline $\begin{array}{l}\text { Slowness } \\
\text { D4 } \\
\text { TUG (M } \pm S D)\end{array}$ & $\begin{array}{c}<10 \\
48(35.3)\end{array}$ & $\begin{array}{c}\geq 10 \\
88(64.7)\end{array}$ \\
\hline $\begin{array}{l}\text { Weakness } \\
\text { D5 }\end{array}$ & $\begin{array}{c}\text { No } \\
84(62.2)\end{array}$ & $\begin{array}{c}\text { Yes } \\
51(37.8)\end{array}$ \\
\hline Total score $(M \pm S D)$ & \multicolumn{2}{|c|}{$1.7 \pm 1.2$} \\
\hline
\end{tabular}

Note: $D$ - dimension; TUG - Timed Up and Go; $M$ - mean; SD - standard deviation.

Table 2 presents the results of hand grip strength with 3 different cut-offs. The number of frail older people is relatively higher when considering cut-off $A(n=36,26.5 \%)$ in relation to cut-offs $B$ and $C$ (both with $n=27,19.9 \%)$.

Table 2 - Analysis of different cut-offs of hand grip strength in the prevalence of frailty ( $N=136)$, Porto metropolitan area, Vila Nova de Gaia, Portugal, 2017

\begin{tabular}{|c|c|c|c|c|}
\hline \multirow{2}{*}{ Dimension } & \multirow{2}{*}{\multicolumn{2}{|c|}{ Cut-off }} & \multicolumn{2}{|c|}{ Phenotype n(\%) } \\
\hline & & & Non-frail & Frail \\
\hline \multirow{3}{*}{ Weaknesses } & A & $\begin{array}{l}<18 \mathrm{~kg} \text { (Female) } \\
<31 \mathrm{~kg} \text { (Male) }\end{array}$ & $100(73.5)$ & $36(26.5)$ \\
\hline & B & $\begin{array}{l}<16 \mathrm{~kg} \text { (Female) } \\
<27 \mathrm{~kg} \text { (Male) }\end{array}$ & 109(80.1) & $27(19.9)$ \\
\hline & $\mathrm{C}$ & $\begin{array}{l}<16 \mathrm{~kg} \text { (Female) } \\
<26 \mathrm{~kg} \text { (Male) }\end{array}$ & 109(80.1) & $27(19.9)$ \\
\hline
\end{tabular}

\section{Comparison of frail versus non-frail groups}

In the comparison of frail and non-frail older people (Table 3) with sociodemographic variables, significant results were found for older people (categorized age (years): $x^{2}(2)=9.0 p=0.011$, quantitative age (years): $U=943.0 p<0.001$ ), negative self-rated health $\left(X^{2}(2)=14.577 ; p=0.001\right)$, and higher physical capacity $(U=831.0$; $\mathrm{p}<0.001)$. There were no statistically significant associations between frail and non-frail groups for sex, marital status, BMI and clinical history as well as no significant differences with the number of people living in the same house (Table 3).

Table 3 - Comparison of frail versus non-frail groups, Porto metropolitan area, Vila Nova de Gaia, Portugal, 2017

\begin{tabular}{cccc}
\hline & $\begin{array}{c}\text { Non-frail } \\
(\mathbf{n = 1 0 0 )}\end{array}$ & $\begin{array}{c}\text { Frail } \\
(\mathbf{n}=\mathbf{3 6})\end{array}$ & $\begin{array}{c}\text { Statistical } \\
\text { test }\end{array}$ \\
\hline $\begin{array}{c}\text { Qualitative variables } \\
\text { Sex }\end{array}$ & $\mathbf{n}(\%)$ & $\mathbf{n}(\%)$ & \\
$\quad$ Male & & & \\
$\quad$ Female & $51(77.3)$ & $15(2.7)$ & $\begin{array}{c}X 2(1)=0.9 \\
p=0.337\end{array}$ \\
$\begin{array}{c}\text { Age (years) } \\
\text { 65-74 }\end{array}$ & $49(70.0)$ & $21(30.0)$ & \\
$75-84$ & $64(83.1)$ & $13(16.9)$ & \\
$\geq 85$ & $32(62.7)$ & $19(37.3)$ & $X 2(2)=9.0$ \\
& $4(50.0)$ & $4(50.0)$ & $p=0.011$ \\
\hline & & & To be continued
\end{tabular}

Table 3 (concluded)

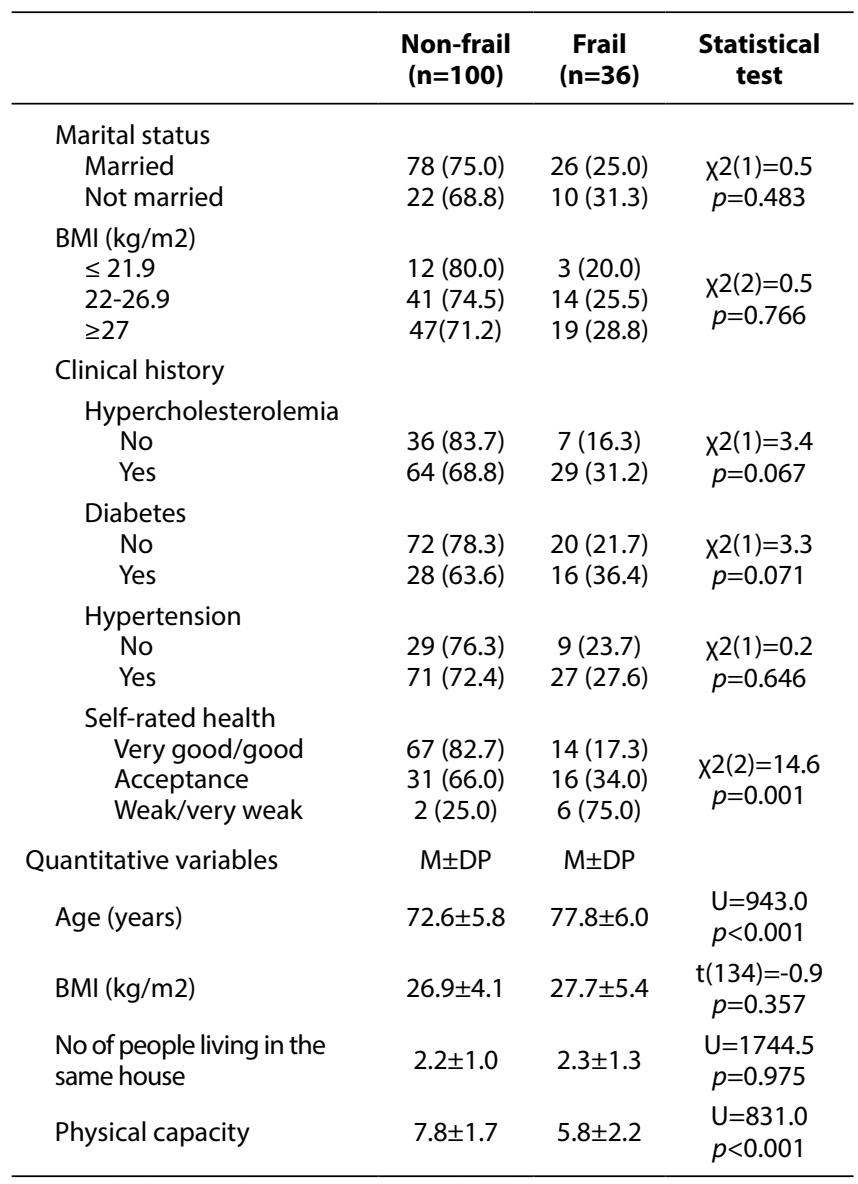

Note: $B M I$ - body mass index; $M$ - mean; SD - standard deviation.

\section{Predictors of frailty}

In the univariate analysis, it was observed that older people are more likely to be frailer $(\mathrm{OR}=1.155 ; 95 \% \mathrm{Cl}=1.077-1.239)$. Of the clinical variables, the FS'OR was significant with people who presented an acceptable self-rated health $(\mathrm{OR}=2.470 ; 95 \% \mathrm{Cl}=1.073-5.688)$ or weaker $(\mathrm{OR}=14.357 ; 95 \% \mathrm{Cl}(2.621-78.653)$ when compared to the group who rated their health as being very good/good (reference group) and with worse physical capacity $(\mathrm{OR}=0.591 ; 95 \% \mathrm{Cl}=0.465$ 0.752 (Table 4).

Table 4 - Predictors of frailty of older people identified through binary logistic regression analysis, Porto metropolitan area, Vila Nova de Gaia, Portugal, 2017

\begin{tabular}{llll}
\hline \multicolumn{2}{c}{ Univariable } & \multicolumn{2}{c}{ Multivariate } \\
Odds & $95 \% \mathrm{Cl}$ & $\begin{array}{l}\text { Odds } \\
\text { Ratio }\end{array}$ & $95 \% \mathrm{Cl}$ \\
\hline
\end{tabular}

Qualitative variables

Sex

Male

Female

Categorized age (years)

65-74

75-84

$\geq 85$

Marital status

Married

Not married

BMI (Lipschitz) (kg/m2)

$\leq 21.9$

22-26.9

27 n.a.

$2.923 * \quad 1.283-6.658$

4.923* $1.089-22.257$

$\begin{array}{cc}1 & - \\ 1364 & 0.572-3.253\end{array}$

$1 \quad-$

$1.617 \quad 0.410-6.381$
$1.366 \quad 0.336-5.556$ 
Table 4 (concluded)

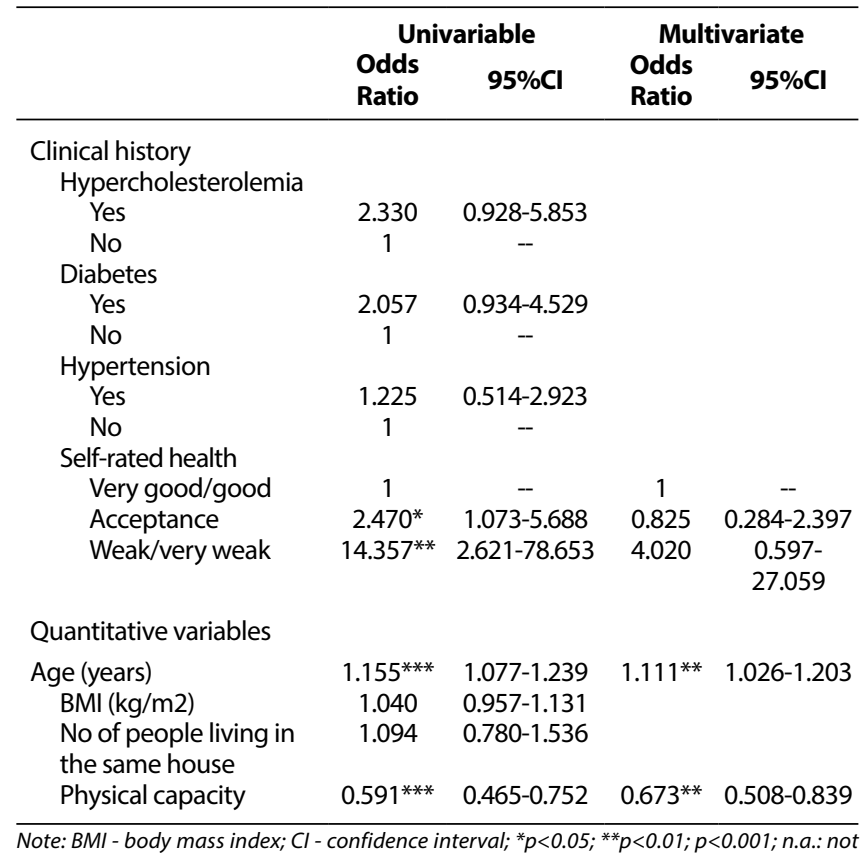

In the multivariate analysis (Table 4), it was observed that a significant $O R$ of observing frailty for an older age $(O R=1.111$; $95 \% \mathrm{Cl}=1.026-1.203)$ and with worse physical capacity $(\mathrm{OR}=0.673$; $95 \% \mathrm{Cl}=0.508-0.893)$. Age and physical capacity were shown to be significant as predictors of FS than the self-rated health variable ( $p>0.05$ ). The proportion of variability explained by the model varies between $27.3 \%$ and $39.9 \%$, with Cox-Snell values $R^{2}$ and $\mathrm{R}^{2}$ being considered low. The Hosmer and Lemeshow goodnessof-fit test indicates that the model is appropriate to the data, and the existence of a statistical model was verified.

\section{DISCUSSION}

The identification of frailty as well as predictors of FS are central to the development of a care plan for older people in PHC. In this study, more than four of the older people investigated were considered frail, this value being higher when compared to data from a systematic review ( $\mathrm{n}=45$ studies) carried out in Europe with FP (26.5\% versus $12 \%)^{(7)}$. However, other studies carried out in the community report higher values ${ }^{(25-26)}$. Compared to studies carried out in Portugal, the prevalence of frail older people in the work on screen was lower ${ }^{(11-12)}$. Duarte's ${ }^{(13)}$ results are the closest to those reported in this study, probably because he used the same adapted version of the FP. However, other studies using the FP report significantly different values $^{(27)}$. It should be noted that these older people spontaneously sought services in PHC, which may favor smaller portions of the FS. The frailest people may not use these services due to the severity of this condition, which may limit access to these services. Additionally, different data are reported in the literature, in which the prevalence of frailty is influenced by the definition of frailty, type of instrument used, operationalization of the FP and sampling criteria, which may limit the comparability between studies ${ }^{(6)}$.

In this study, it was possible to verify that the use of different cut-offs of handgrip strength influenced the prevalence of frailty. Although there is no consensus on the best values for handgrip strength cut-offs ${ }^{(21)}$, this FP component may have a significant role in frailty ${ }^{(28)}$ and should be considered according to the objective of the investigation. Additionally, handgrip strength proved to be an indicator of older people's health status, being related to adverse events, namely, mortality and disability ${ }^{(29)}$. Comparing the frail group with the non-frail group, people from the frail group were older and had a lower self-rated health, corroborating data from other studies $^{(6,9,18)}$, suggesting the importance of self-rated health as a significant risk factor ${ }^{(18)}$. Another predictor for FS was worse physical ability. These data are in line with the study on physical activity in frail older people, where $58.4 \%$ showed a decrease in the level of physical activity and there was a statistically significant association between frailty and physical activity ${ }^{(28)}$. In the univariate model, it was observed that older people, with an acceptable or weak selfrated health, and worse physical capacity, are frailer. These data corroborate the systematic review studies that demonstrate the positively significant association with frailty ${ }^{(6,9)}$. With regard to other predictors, in this study, female sex was not a predictor for frailty, contrary to what was reported in systematic review studies ${ }^{(9)}$. A possible explanation may be the smaller number of females included in this study, significantly lower than other studies ${ }^{(6,9,18)}$. BMI also proved not to be a predictor, not corroborating other studies that report that this variable has a significant association with $\mathrm{FS}^{(9)}$. The clinical history included also did not show a statistically significant difference. However, these were analyzed in isolation. A possible grouping considering multimorbidity (coexistence of multiple diseases and medical conditions in a person) could be considered, since its presence represents a risk factor for $\mathrm{FS}^{(30)}$. Marital status and the number of people in the household did not prove to be a predictor, unlike other studies ${ }^{(6,9)}$. This result may be due to the fact that most respondents live with their spouse (76.5\%), and surveys suggest that marital status is more relevant for people who are alone, such as single men and people who have lost the spouse.

As predictors of frailty, in the multivariate model, only the variables age and physical capacity stand out. Several studies corroborate the results regarding the predictive value of these variables $^{(6,9,31)}$. Data reported in other studies demonstrate that physical activity was negatively correlated with FS, constituting, in a statistically significant way, a protective factor when high $^{(28,31)}$. In this study, comparing subjective physical activity with objective measures, such as the TUG test and the handgrip strength test, it was possible to observe that older people with better physical condition are less frail. These results reinforce a strong correlation between these tests and the increased prevalence of frailty ${ }^{(18,28)}$.

\section{Study limitations}

This study has limitations. First, the sample size inferring from that foreseen in its calculation is highlighted. This situation was due to logistical issues, such as the researcher's time and changes in the unit team. Second, this study was carried out in a single PHC unit, with a convenience sample, limiting generalization to other units. Third, the existence of a large variability regarding the operationalization of the FP, which may limit the comparability of results between studies ${ }^{(1)}$. Fourth, in the operationalization of clinical predictors, each pathology was considered as a predictor in isolation. Future studies should consider the presence of multimorbidity as a predictor, as 
suggested in the literature ${ }^{(30)}$. Finally, there is no information available on the characteristics of older people who refused to participate in the study, which makes it difficult to generalize the results of our sample to other populations residing in the community.

\section{Contributions to nursing, health, and public policies}

PHC health professionals, namely nurses, are in a strategic position to recognize the FS, with FP being one of the instruments to be included in clinical practice. Through this screening, they can identify frail older people in order to mitigate their progression and prevent their adverse events. This study, by identifying the predictors of frailty in PHC users, especially the low level of physical activity, can guide the development of strategies directed by nurses. Thus, implementing and evaluating nursing interventions aimed at promoting physical activity in frail older people in $\mathrm{PHC}$ should be considered in future studies, especially because it is a potentially modifiable risk factor and can prevent or mitigate the progression of this syndrome.

\section{CONCLUSIONS}

The prevalence of frailty in the elderly in the analyzed PHC unit was considerable, which reinforces the importance of early recognition of patients with FS. In this study, this value was influenced by the operationalization of the FP, namely, by handgrip strength cut-offis. Frail older people were those who were older, self-rated their health as lower and with worse physical capacity. In the univariate analysis, it was observed that older people with acceptable or weak self-rated health, and worse physical capacity are frailer. As predictors of frailty, in the multivariable regression model, age and physical capacity stand out. The older the elderly person is, the greater the OR of being frail. With regard to physical ability, the worse it is, the greater the OR of frailty.

\section{SUPPLEMENTARY MATERIAL}

Repository Data: Machado I. Identificação de pessoas idosas frágeis na comunidade [Internet]. Universidade de Aveiro; 2018 [cited 2021 Sep 1]. Available from: http://hdl.handle.net/10773/23031.

\section{FUNDING}

This article was supported by National Funds through the FCT (Foundation for Science and Technology - Fundação para a Ciência e a Tecnologia), I.P., within the scope of CINTESIS, R\&D Unit (reference UIDB/4255/2020).

\section{REFERENCES}

1. Hoogendijk EO, Afilalo J, Ensrud KE, Kowal P, Onder G, Fried LP. Frailty: implications for clinical practice and public health. Lancet. 2019;394(10206):1365-75. https://doi.org/10.1016/S0140-6736(19)31786-6

2. Fried LP, Tangen CM, Walston J, Newman AB, Hirsch C, Gottdiener J, et al. Frailty in older adults: evidence for a phenotype. J Gerontol A Biol Sci Med Sci. 2001;56(3):M146-57. https://doi.org/10.1093/gerona/56.3.m146

3. Rockwood K. A global clinical measure of fitness and frailty in elderly people. Can Med Assoc J. 2005;173(5):489-95. https://doi.org/10.1503/ cmaj.050051

4. Gobbens RJ, Luijkx KG, Wijnen-Sponselee MT, Schols JM. Toward a conceptual definition of frail community dwelling older people. Nurs Outlook. 2010;58(2):76-86. https://doi.org/10.1016/j.outlook.2009.09.005

5. Morley JE, Vellas B, van Kan GA, Anker SD, Bauer JM, Bernabei R, et al. Frailty consensus: a call to action. J Am Med Dir Assoc. 2013;14(6):39297. https://doi.org/10.1016/j.jamda.2013.03.022

6. Apóstolo J, Cooke R, Bobrowicz-Campos E, Santana S, Marcucci M, Cano A, et al. Predicting risk and outcomes for frail older adults: an umbrella review of frailty screening tools. JBI database Syst Rev Implement Repor. 2017;15(4):1154-208. https://doi.org/10.11124/ JBISRIR-2016-003018

7. O'Caoimh R, Galluzzo L, Rodríguez-Laso Á, Van der Heyden J, Ranhoff AH, Lamprini-Koula M, et al. Prevalence of frailty at population level in European ADVANTAGE Joint Action Member States: a systematic review and meta-analysis. Ann Ist Super Sanita. 2018;54(3):226-38. https:// doi.org/10.4415/ANN_18_03_10

8. Manfredi G, Midão L, Paúl C, Cena C, Duarte M, Costa E. Prevalence of frailty status among the European elderly population: findings from the Survey of Health, Aging and Retirement in Europe. Geriatr Gerontol Int. 2019;19(8):723-9. https://doi.org/10.1111/ggi.13689

9. Feng Z, Lugtenberg M, Franse C, Fang $X, \mathrm{Hu}$ S, Jin C, et al. Risk factors and protective factors associated with incident or increase of frailty among community-dwelling older adults: A systematic review of longitudinal studies. PLoS One. 2017;12(6):e0178383. https://doi. org/10.1371/journal.pone.0178383

10. Chang SF, Wen GM. Association of frail index and quality of life among community-dwelling older adults. J Clin Nurs. 2016;25(15-16):230516. https://doi.org/10.1111/jocn.13248

11. Santiago LM, Silva R, Velho D, Rosendo I, Simões J. Cross-cultural adaptation and validation of the PRISMA-7 scale for European Portuguese. Fam Med Prim Care Rev. 2020;22(1):59-66. https://doi.org/10.5114/fmpcr.2020.92507

12. Lourenço RA, Moreira VG, Banhato EFC, Guedes DV, Silva KCA, Delgado FEF, et al. Prevalence of frailty and associated factors in a community-dwelling older people cohort living in Juiz de Fora, Minas Gerais, Brazil: Fibra-JF Study. Cien Saude Colet. 2019;24(1):35-44. https://doi.org/10.1590/1413-81232018241.29542016 
13. Duarte M, Paúl C. Prevalence of phenotypic frailty during the aging process in a Portuguese community. Rev Bras Geriatr e Gerontol. 2015;18(4):871-80. https://doi.org/10.1590/1809-9823.2015.14160

14. Apóstolo J, Cooke R, Bobrowicz-Campos E, Santana S, Marcucci M, Cano A, et al. Effectiveness of interventions to prevent pre-frailty and frailty progression in older adults. JBI Database Syst Rev Implement Reports. 2018;16(1):140-232. https://doi.org/10.11124/ JBISRIR-2017-003382

15. Walston J, Buta B, Xue QL. Frailty Screening and Interventions: Considerations for Clinical Practice. Clin Geriatr Med. 2018;34(1):25-38. https://doi.org/10.1016/j.cger.2017.09.004

16. Wang MC, Li TC, Li Cl, Liu CS, Lin WY, Lin CH, et al. Frailty, transition in frailty status and all-cause mortality in older adults of a Taichung community-based population. BMC Geriatr. 2019;19(1):26. https://doi.org/10.1186/s12877-019-1039-9

17. Theou O, Cann L, Blodgett J, Wallace LMK, Brothers TD, Rockwood K. Modifications to the frailty phenotype criteria: Systematic review of the current literature and investigation of 262 frailty phenotypes in the Survey of Health, Ageing, and Retirement in Europe. Ageing Res Rev. 2015;21:78-94. https://doi.org/10.1016/j.arr.2015.04.001

18. Duarte M. Fragilidade em Idosos: modelos, medidas e implicações práticas. Lisboa: Coisas de Ler; 2015.

19. Sousa-Santos AR, Amaral TF. Differences in handgrip strength protocols to identify sarcopenia and frailty: a systematic review. BMC Geriatr. 2017;17(1):238. https://doi.org/10.1186/s12877-017-0625-y

20. Kerr A, Syddall HE, Cooper C, Turner GF, Briggs RS, Sayer AA. Does admission grip strength predict length of stay in hospitalised older patients? Age Ageing. 2006;35(1):82-4. https://doi.org/10.1093/ageing/afj010

21. Cruz-Jentoft AJ, Bahat $G$, Bauer J, Boirie $Y$, Bruyère $O$, Cederholm $T$, et al. Sarcopenia: revised European consensus on definition and diagnosis. Age Ageing. 2019;48(1):16-31. https://doi.org/10.1093/ageing/afz046

22. Studenski SA, Peters KW, Alley DE, Cawthon PM, McLean RR, Harris TB, et al. The FNIH Sarcopenia Project: Rationale, Study Description, Conference Recommendations, and Final Estimates. J Gerontol A Biol Sci Med Sci. 2014;69(5):547-58. https://doi.org/10.1093/gerona/glu010

23. Zar JH. Biostatistical Analysis, 5th Edition. River, NJ: Prentice Hall; 2010. $944 \mathrm{p}$

24. Hosmer DW, Lemeshow S, Sturdivant RX. Applied Logistic Regression (3rd Edition). New York: John Wiley \& Sons; 2013.528 p.

25. Llano PMP, Lange C, Sequeira CAC, Jardim VMR, Castro DSP, Santos F. Factors associated with frailty syndrome in the rural elderly. Rev Bras Enferm. 2019;72(suppl 2):14-21. https://doi.org/10.1590/0034-7167-2017-0079

26. Saenger ALF, Caldas CP, Raîche M, da Motta LB. Identifying the loss of functional independence of older people residing in the community: Validation of the PRISMA-7 instrument in Brazil. Arch Gerontol Geriatr. 2018;74:62-7. https://doi.org/10.1016/j.archger.2017.09.008

27. Duarte YAO, Nunes DP, Andrade FB, Corona LP, Brito TRP, Santos JLF, et al. Frailty in older adults in the city of São Paulo: prevalence and associated factors. Rev Bras Epidemiol. 2018;21(suppl 2):E180021. https://doi.org/10.1590/1980-549720180021.supl.2

28. Lenardt MH, Binotto MA, Carneiro NHK, Cechinel C, Betiolli SE, Lourenço TM. Handgrip strength and physical activity in frail elderly. Rev Esc Enferm USP. 2016;50(1):86-92. https://doi.org/10.1590/S0080-623420160000100012

29. Soysal P, Hurst C, Demurtas J, Firth J, Howden R, Yang L, et al. Handgrip strength and health outcomes: Umbrella review of systematic reviews with meta-analyses of observational studies. J Sport Heal Sci. 2021;10(3):290-5. https://doi.org/10.1016/j.jshs.2020.06.009

30. Kernick D, Chew-Graham CA, O'Flynn N. Clinical assessment and management of multimorbidity: NICE guideline. Br J Gen Pract. 2017;67(658):235-6. doi: 10.3399/bjgp17X690857

31. Sewo Sampaio PY, Sampaio RAC, Coelho Jr HJ, Teixeira LFM, Tessutti VD, Uchida MC, et al. Differences in lifestyle, physical performance and quality of life between frail and robust Brazilian community-dwelling elderly women. Geriatr Gerontol Int. 2016;16(7):829-35. https://doi. org/10.1111/ggi.12562 